\title{
Aquaculture Effluent: Effect on Yield, Nutrient Content and Uptake in Salicornia bachiata Roxb
}

\author{
Narendra Singh ${ }^{1 *}$, Ampee Tasung ${ }^{1}$, Sonal Tripathi ${ }^{1}$, Pathik Baldev Patel ${ }^{2}$, Ajeet Mulchand Bafna ${ }^{1}$ and Rattan Govind Patil ${ }^{2}$ \\ ${ }^{1}$ Department of Soil Science and Agricultural Chemistry, N. M. College of Agriculture, Navsari Agricultural University-Navsari-396 450, Gujarat, India \\ ${ }^{2}$ Soil and Water Management Research Unit, Navsari Agricultural University, Navsari 396450, Gujarat, India
}

\begin{abstract}
The feasibility of aquaculture effluent as irrigation water for Salicornia brachiata Roxb. was determined to access the effect of effluent on fresh biomass, dry biomass, nutrient content and uptake. A field experiment was conducted using split plot design (SPD) with three factors (S- Sources of irrigation, M-Methods of sowing, F-Levels of fertilizer) at Central Soil Salinity Research Station, Dhanti-Umbharat, Navsari, India. The fresh and dry biomass yield of Salicornia was higher with the application of aquaculture effluent water to sea water irrigation. An application of 125:75:50 RDF of NPK conspicuously increased the fresh and dry biomass yield. The interaction study between the aquaculture effluent irrigation and 125:75:50 RDF of NPK on the fresh and dry biomass yield was significant. The individual effect of aquaculture effluent and 125:75:50 RDF of NPK were significant in the plant primary and secondary nutrient content and uptake. Concomitantly, the interaction of aquaculture effluent irrigation and 125:75:50 RDF of NPK was significant in plant primary and secondary nutrient uptake. In completion of the analysis, there was $40-50 \%$ nutrient saving with using aquaculture effluent.
\end{abstract}

Keywords: Aquaculture; Effluent; Salicornia brachiata; Irrigation; Nutrient uptake; Yield

\section{Introduction}

Water bodies are subjected to various forms of environmental pollution. The two percent of fresh water in the twenties is dwindling at a faster rate making it difficult for agricultural sector to meet even the marginal quantity for obtaining a good yield. The abundant of water in the sea remains unfit for consumption as well as agriculture due to the high salt concentration. In arid and semi-arid region of the world availability of good quality water is very crucial for livelihood, livestock and agriculture. In the contrary aquaculture industry flushes out nutrient load effluent in large quantity into the soil and water bodies. These effluent if not treated can cause environmental disrupt making natural sustenance very difficult. Untreated effluent may damage coastal ecosystems and fisheries [1-8].

In consensus of the seawater availability we are owed to find production alternatives to dissipate the burden load on fresh water. Integrating vegetable hydroponics with fish culture is another effective but expensive technique to remove nutrients from a fish culture system [9]. The subject of availability of good quality water and expense in treatment of effluent can be compensated by halophytes. Halophytes have potential to produce biomass, forage and oilseed crops using saltwater irrigation [1014]. Halophytes as biofilters in plant-soil system removed $98 \%$ and $94 \%$ of the applied total and inorganic nitrogen and removed $99 \%$ and $97 \%$ of the applied total and soluble reactive phosphorus, respectively [15]

Salicornia, an obligate halophyte can adapt to adverse salinity stress and produce vegetable salt, forage crop and seed oil. Salicornia intimates the salinity of seawater and are known to flourish in the coastal area. An optimum plant density of 278 plant $/ \mathrm{m}^{2}$ and $100 \mathrm{~kg} \mathrm{~N} / \mathrm{ha}$ and $75 \mathrm{~kg}$ $\mathrm{P}_{2} \mathrm{O}_{5} /$ ha had good impact on improvement of vegetable biomass and oil of Salicornia brachiata [16]. In this study we investigated the suitability of Salicornia to develop with aquaculture emanating water as Irrigation and their response to fertilizer application.

\section{Materials and Methods}

\section{Experimental design and procedures}

The study was conducted in June-December 2013 in the field at
Dhanti-Umbharat Reasarch Station, Navsari, India. Geographically, Danti-Umbharat is situated at $20^{\circ} 83^{\prime} \mathrm{N}$ latitude and $72^{\circ} 50^{\prime} \mathrm{E}$ longitudes with an elevation of 2.5 meter above sea level on the western coastal belt of India. During the growing period the maximum and minimum temperature was $35^{\circ} \mathrm{C}$ and $17.2^{\circ} \mathrm{C}$ and the relative humidity ranged from 33.5 percent to $89.6 \%$. The experimental study was carried out with split plot design. In the main plot, source of irrigation was allotted, and in the subplot combination of methods of sowing and levels of fertilizer was allotted. Two source of irrigation $\left(\mathrm{S}_{1}\right.$-Seawater, $\mathrm{S}_{2}$ Aquaculture effluent), two methods of sowing ( $\mathrm{M}_{1}$-Broadcasting, $\mathrm{M}_{2}$ Line sowing with spikelet) and three levels of fertilizer $\left[\mathrm{F}_{1}\right.$-no fertilizer (control), $\mathrm{F}_{2}-125: 37.5: 25$ NPK (50\% RDF), $\mathrm{F}_{3}-250: 75: 50$ NPK (100\% $\mathrm{RDF})]$ were used in four replications of the treatment combinations. The aquaculture effluent water was drawn from the nearby shrimp pond at the station and seawater was drawn from the coast of Arabian Sea. Irrigation applied as and when required from August-December. The primary fertilizers are urea, single super phosphate (SSP) and murate of potash (MoP) to supply NPK nutrients.

\section{Soil, water and plant analyses}

Soil samples were collected before sowing and after harvest at 0-15 $\mathrm{cm}$ depth. The $\mathrm{pH}$ and $\mathrm{EC}$ was determined by conductometric method, organic carbon by Walkely and Black Jackson [17] method, availed nitrogen by Subbiah and Ashija [18] method, available $\mathrm{P}_{2} \mathrm{O}_{5}$ by Olsen et al. [19], available $\mathrm{K}_{2} \mathrm{O}$ by neutral $\mathrm{N}$ ammonium acetate, $\mathrm{Ca}$ and $\mathrm{Mg}$ by complexometric method, available $\mathrm{S}$ by Turbidometric method,

*Corresponding author: Narendra Singh, Department of Soil Science and Agricultural Chemistry, N. M. College of Agriculture, Navsari Agricultura University-Navsari-396 450, Gujarat, India, Tel no: 07835818371; E-mail: narendra_singh85@yahoo.co.in

Received May 25, 2015; Accepted July 27, 2015; Published August 25, 2015

Citation: Singh N, Tasung A, Tripathi S, Patel PB, Bafna AM, et al. (2015) Aquaculture Effluent: Effect on Yield, Nutrient Content and Uptake in Salicornia bachiata Roxb. J Aquac Res Development 6: 376. doi:10.4172/2155-9546.1000376

Copyright: @ 2015 Singh N, et al. This is an open-access article distributed under the terms of the Creative Commons Attribution License, which permits unrestricted use, distribution, and reproduction in any medium, provided the original author and source are credited. 
Citation: Singh N, Tasung A, Tripathi S, Patel PB, Bafna AM, et al. (2015) Aquaculture Effluent: Effect on Yield, Nutrient Content and Uptake in Salicornia bachiata Roxb. J Aquac Res Development 6: 376. doi:10.4172/2155-9546.1000376

Page 2 of 8

available micronutrients by 0.005 M DTPA Atomic Absorption Spectro photo meteric and water stable aggregates by wet sieving method [20]. The soil analysis results are presented in Table 1. Water used as irrigation was collected in clean transparent plastic bottles. The $\mathrm{pH}$, $\mathrm{EC}$, cations, anions, total $\mathrm{N}, \mathrm{P}, \mathrm{K}$ and $\mathrm{S}$ were measured in irrigation water (aquaculture effluent and sea water) using methods of American Public Health Association [21]. The water analysis results are shown in Table 2. The plant shoot tissue after drying were digested with diacid mixture $\left(\mathrm{HNO}_{3}: \mathrm{HClO}_{4}, 10: 4\right)$ and analyzed for total nitrogen with Auto Kjeldhal instrument, total $\mathrm{P}$ by ammonium molybdate vandate yellow colour method, total $\mathrm{S}$ by Turbidometric, total $\mathrm{K}$ and $\mathrm{Na}$ with flamephotometer and total $\mathrm{Ca}$ and $\mathrm{Mg}$ by complexometric method [22].

\section{Statistical analyses}

Data were analyzed by parametric methods using a split plot analysis of variance with source of irrigation as the main plot and combination of methods of sowing and levels of fertilizer as the subplot with four replications. The analyses were carried out using statistical methods given by Panse and Sukhatme [23]. Statistical analyses were conducted to identify the mean, standard error mean (S.Em.) and coefficient of variance $(\mathrm{CV})$ of various parameters. $F$-test was conducted to identify

\begin{tabular}{|c|c|c|c|c|}
\hline \multirow{2}{*}{ Parameter } & \multicolumn{2}{|c|}{ Before harvest } & \multicolumn{2}{c|}{ After harvest } \\
\cline { 2 - 5 } & $\mathbf{S}_{1}$ & $\mathbf{S}_{\mathbf{2}}$ & $\mathbf{S}_{1}$ & $\mathbf{S}_{2}$ \\
\hline $\mathrm{pH}_{(1: 2.5)}$ & 8.31 & 8.14 & 8.43 & 8.44 \\
\hline $\mathrm{EC}_{(1: 2.5)}(\mathrm{dS} / \mathrm{m})$ & 9.57 & 13.26 & 9.00 & 9.12 \\
\hline $\mathrm{OC}(\%)$ & 0.31 & 0.30 & 0.44 & 0.61 \\
\hline $\mathrm{N}(\mathrm{kg} / \mathrm{ha})$ & 234.00 & 248.00 & 344.00 & 465.00 \\
\hline $\mathrm{P}_{2} \mathrm{O}_{5}(\mathrm{~kg} / \mathrm{ha})$ & 20.41 & 21.34 & 18.66 & 26.10 \\
\hline $\mathrm{K}_{2} \mathrm{O}(\mathrm{kg} / \mathrm{ha})$ & 2697.00 & 3091.00 & 3844.00 & 5023.00 \\
\hline $\mathrm{S}(\mathrm{kg} / \mathrm{ha})$ & 39.32 & 45.89 & 22.02 & 24.24 \\
\hline $\mathrm{CEC}$ & 67.15 & 79.19 & 42.64 & 44.17 \\
\hline$(\mathrm{me} 100 / \mathrm{g})$ & 54.52 & 47.74 & 53.38 & 47.23 \\
\hline $\mathrm{ESP}$ & 4.29 & 4.21 & 5.41 & 4.65 \\
\hline $\mathrm{SAR}$ & 5.18 & 3.73 & 5.35 & 6.48 \\
\hline $\mathrm{Fe}(\mathrm{ppm})$ & 3.94 & 4.04 & 3.18 & 4.32 \\
\hline $\mathrm{Mn}(\mathrm{ppm})$ & 1.79 & 1.27 & 0.61 & 0.72 \\
\hline $\mathrm{Zn}(\mathrm{ppm})$ & 0.60 & 5.40 & 0.79 & 1.12 \\
\hline $\mathrm{Cu}(\mathrm{ppm})$ & & & & \\
\hline
\end{tabular}

Table 1: Soil chemical properties of study site before and after harvest.

\begin{tabular}{|c|c|c|}
\hline Parameter & Sea water (S1) & $\begin{array}{c}\text { Aquaculture effluent } \\
\text { (S2) }\end{array}$ \\
\hline $\mathrm{pH}$ & 7.8 & 8.0 \\
\hline $\mathrm{EC}(\mathrm{dS} / \mathrm{m})$ & 41.9 & 43.97 \\
\hline $\mathrm{Ca}^{2+}(\mathrm{me} / \mathrm{l})$ & 16.3 & 17.3 \\
\hline $\mathrm{Mg}^{2+}(\mathrm{me} / \mathrm{l})$ & 27.2 & 30.9 \\
\hline $\mathrm{Na}^{+}(\mathrm{me} / \mathrm{l})$ & 362.0 & 377.0 \\
\hline Carbonates $(\mathrm{me} / \mathrm{l})$ & $\mathrm{Nil}$ & $\mathrm{Nil}$ \\
\hline $\mathrm{Bicarbonates}(\mathrm{me} / \mathrm{l})$ & 7.6 & 8.6 \\
\hline $\mathrm{SO}_{4}{ }^{2-}(\mathrm{me} / \mathrm{l})$ & 11.7 & 10.9 \\
\hline $\mathrm{RSC}(\mathrm{me} / \mathrm{l})(\mathrm{me} / \mathrm{l})$ & $\mathrm{Nil}$ & $\mathrm{Nil}$ \\
\hline $\mathrm{SAR}$ & 77.6 & 76.8 \\
\hline $\mathrm{Cl}(\mathrm{me} / \mathrm{l})$ & 391.0 & 413.0 \\
\hline $\mathrm{Total} \mathrm{N}(\mathrm{mg} / \mathrm{l})$ & 60.6 & 71.2 \\
\hline $\mathrm{P}(\mathrm{mg} / \mathrm{l})$ & 1.5 & 1.75 \\
\hline $\mathrm{K}(\mathrm{mg} / \mathrm{l})$ & 133.0 & 222.0 \\
\hline
\end{tabular}

Table 2: Chemical characteristics of sea water (S1) and aquaculture effluent (S2) used as irrigation water in the experiment. significant differences among means. The significance criterion was P-0.05.

\section{Results}

\section{Fresh and dry biomass yield}

The mean fresh biomass yield ranged from 10.94 to $29.53 \mathrm{t} / \mathrm{ha}$ under sea water irrigation (Table 3 ). The fresh biomass yield was significantly higher in the F3 than control treatment F1 (no fertilizer). Although the green matter yield was superior as compared to F2, the difference in yield between these treatments was not significant at $5 \%$ level of significance. The results indicated that the optimum green matter production could be obtained by applying only $50 \%$ of recommended dose of fertilizer further does of $\mathrm{N}$ may not be beneficial as observed under the present investigation due to insignificant difference in yield. The range of green matter yield was 15.18 to $42.23 \mathrm{t} / \mathrm{ha}$ in different fertilizer treatments irrigated with aquaculture effluents (Table 3 ). The green matter yield was significantly more in F3 (100\% RDF) fertilizer treatment than control treatment (F1) as well as F2 treatment (50\% RDF) plots.

The analysis of results showed that the fresh biomass production was higher in F1, F2 and F3 treatment plots (irrigated with aquaculture effluent and receiving 0,50 and $100 \% \mathrm{RDF}$ ) as compared to $\mathrm{F} 1, \mathrm{~F} 2$ and F3 (irrigated with sea water and receiving 0, 50 and 100\% of RDF) fertilizer treatment plots. This would mean that green matter yield of 37.44 to $42.23 \mathrm{t} / \mathrm{ha}$ (Table 3 ) can be obtained by applying only 50 to $100 \% \mathrm{RDF}$ if irrigated with aquaculture effluent containing higher amount of nutrient than seawater. It is concluded therefore, that up to $50 \%$ saving in fertilizer can be achieved in farm where crop irrigation is possible with aquaculture effluent containing residual nutrients.

The mean dry matter yield ranged from 1.31 to $3.55 \mathrm{t} / \mathrm{h}$ a for different fertilizer treatments irrigated with seawater effluent (Table 3). The dry matter yield was significantly more in fertilizer treated plots than in control treatments (F1) plots. Though the dry matter yield showed higher trends with the increased fertilizer application the difference in yield was not significant among F2 and F3 fertilizer treatments.

The mean dry matter yield obtained in F1, F2 and F3 fertilizer treatment plots (irrigated with aquaculture effluent and receiving 0,50 and $100 \% \mathrm{RDF}$ ) was superior with yield obtained in F1, F2 and F3 fertilizer treatment plots (irrigated with sea water and receiving 0,50 and $100 \% \mathrm{RDF}$ ). The analysis of results indicated that higher amount of nutrients present in aquaculture effluent played significant role in meeting some of the crop nutrient needs. This differential role of nutrients in the aquaculture effluent was clearly indicated by the dry

\begin{tabular}{|c|c|c|c|c|c|c|c|c|}
\hline & \multicolumn{4}{|c|}{ Fresh biomass } & \multicolumn{4}{|c|}{ Dry biomass } \\
\hline & $\mathrm{S}_{1}$ & $\mathrm{~S}_{2}$ & \multicolumn{2}{|c|}{ Mean F } & $\mathrm{S}_{1}$ & $\mathrm{~S}_{2}$ & \multicolumn{2}{|c|}{ Mean F } \\
\hline$F_{1}$ & 10.94 & 15.18 & \multicolumn{2}{|l|}{13.06} & 1.31 & 1.83 & \multicolumn{2}{|l|}{1.57} \\
\hline$F_{2}$ & 27.22 & 37.44 & \multicolumn{2}{|l|}{32.33} & 3.27 & 4.49 & \multicolumn{2}{|l|}{3.88} \\
\hline$F_{3}$ & 29.53 & 42.23 & \multicolumn{2}{|l|}{35.88} & 3.55 & 5.07 & \multicolumn{2}{|l|}{4.31} \\
\hline \multirow[t]{2}{*}{$\begin{array}{l}\text { M e a } n \\
\text { (S) }\end{array}$} & 22.56 & 31.62 & & & 2.71 & 3.79 & & \\
\hline & $\mathbf{S}$ & M & $\mathbf{F}$ & SF & $\mathbf{S}$ & $\mathbf{M}$ & $\mathbf{F}$ & SF \\
\hline SEM \pm & 0.86 & 0.92 & 1.13 & 1.59 & 0.10 & 0.11 & 0.14 & 0.19 \\
\hline \multirow[t]{2}{*}{$C D_{(0.05)}$} & 3.88 & NS & 3.25 & 4.60 & 0.47 & NS & 0.39 & 0.55 \\
\hline & \multicolumn{2}{|c|}{ Main plot } & \multicolumn{2}{|c|}{ Sub plot } & \multicolumn{2}{|c|}{ Main plot } & \multicolumn{2}{|c|}{ Sub plot } \\
\hline CV \% & \multicolumn{2}{|l|}{15.60} & \multicolumn{2}{|l|}{16.64} & \multicolumn{2}{|l|}{15.60} & \multicolumn{2}{|l|}{16.64} \\
\hline
\end{tabular}

Table 3: Effect of sea water $\left(\mathrm{S}_{1}\right)$ and aquaculture effluent $\left(\mathrm{S}_{2}\right)$ irrigation along with various fertilizer levels $\left[F_{1}\right.$-no fertilizer (control), $F_{2}-125: 37.5: 25$ NPK (50 percent RDF), $F_{3}-250: 75: 50$ NPK (100 percent RDF)] on fresh biomass yield (t/ha) and dry dry biomass yield of Salicornia brachiate. 
Citation: Singh N, Tasung A, Tripathi S, Patel PB, Bafna AM, et al. (2015) Aquaculture Effluent: Effect on Yield, Nutrient Content and Uptake in Salicornia bachiata Roxb. J Aquac Res Development 6: 376. doi:10.4172/2155-9546.1000376

matter yield obtained in control plots irrigated with sea water $(1.31 \mathrm{t} /$ ha) and aquaculture effluent ( $1.83 \mathrm{t} / \mathrm{ha})$.

\section{Nutrient content and uptake}

\section{Nutrient content}

Primary nutrient content: The mean $\mathrm{N}$ content in the above ground parts of Salicornia ranged from 0.45 to $0.86 \%$ under sea water irrigation (Figure 1). We observed an increasing order in total $\mathrm{N}$ content from control plot F1 (no fertilizer) to $\mathrm{F} 3$ plot (100\% RDF) (Figure 1). The total $\mathrm{N}$ content was significantly highest with an application of $100 \% \mathrm{RDF}$ with seawater irrigation. The results shows the mean range of total $\mathrm{N}$ content of Salicornia was from 0.69 to 0.90 percent in aquaculture effluent irrigated plot (Figure 1). Therefore, the total N content of Salicornia aquaculture effluent irrigated plots was significantly superior over the other plots irrigated with seawater. In the seawater irrigated plots, underground and above ground parts of Salicornia were comparatively less vigorous then the plants in the aquaculture irrigated plots.

The data recorded that the total $\mathrm{P}$ content in the plant ranged from 0.12 to $0.22 \%$ with seawater irrigation (Figure 2). The data observed an increasing trend in total P content from F1 (control) to F3 (100\% RDF). In the aquaculture effluent irrigated plot, the total $\mathrm{P}$ content recorded 0.17 to $0.26 \%$ (Figure 3 ) and similar increasing trend was observed from F1 to F3 under aquaculture irrigation. The data accentuate that total P content of Salicornia in the F1, F2 and F3 plot irrigated with aquaculture effluent were significantly higher in $\mathrm{P}$ content than the counter plots irrigated with seawater.

The mean total K content in Salicornia ranged from 0.57 to $0.65 \%$ with seawater irrigation (Figure 4). Besides an increasing order in total $\mathrm{K}$ content from control treatment F1 (no fertilizer) to F3 (100\% $\mathrm{RDF}$ ), there was no significant different between the F1 (control) and F2 (50\% RDF) and between F2 and F3 (100\% RDF). The result obtained showed that the mean total K content in Salicornia ranged from 0.59 to 0.68 percent under aquaculture effluent irrigation (Figure 5). Consequently, the total $\mathrm{K}$ content showed an increasing trend with increase in RDF. The result showed superiority in the F1, F2 and F3 plots under aquaculture irrigation than seawater irrigation. From the research it indicate that with the application of $50 \% \mathrm{RDF}$ and irrigation with aquaculture effluent can meet the optimum plant $\mathrm{K}$ nutrient

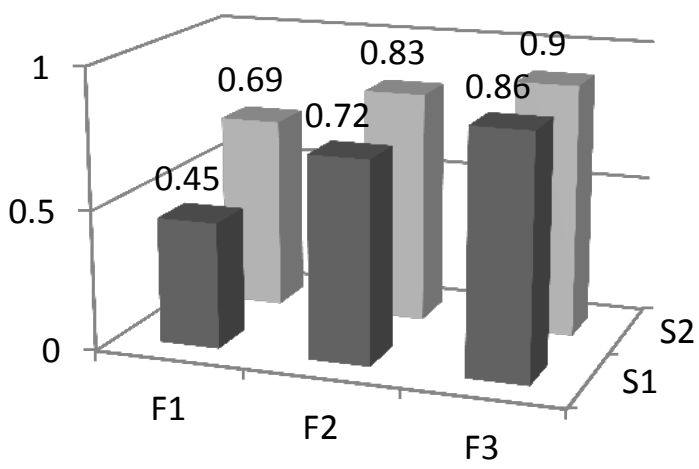

Figure 1: Total $\mathrm{N}$ nutrient content (\% per dry weight) of Salicornia brachiata grown under sea water $\left(S_{1}\right)$ and aquaculture effluent $\left(S_{2}\right)$ irrigation along with various fertilizer levels [ $F_{1}$-no fertilizer (control), $F_{2}-125: 37.5: 25$ NPK (50 per cent RDF), $F_{3}-250: 75: 50$ NPK (100 per cent RDF)].

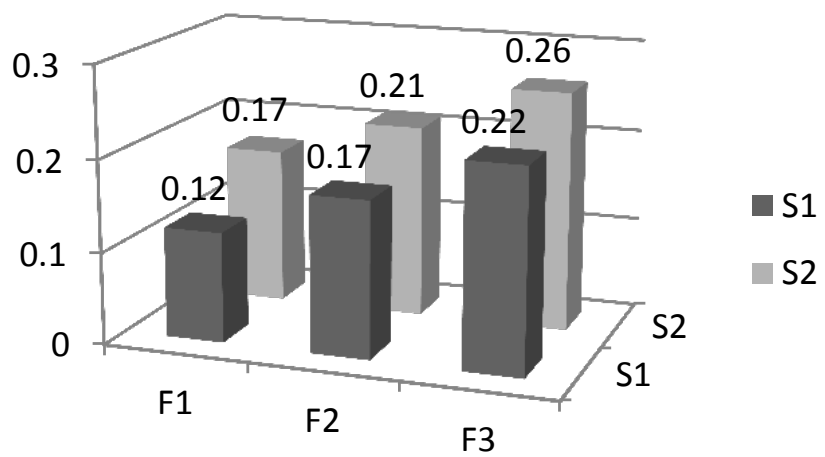

Figure 2: Total P nutrient content (\% per dry weight) of Salicornia brachiata grown under sea water $\left(\mathrm{S}_{1}\right)$ and aquaculture effluent $\left(\mathrm{S}_{2}\right)$ irrigation along with various fertilizer levels [ $F_{-}$-no fertilizer (control), $F_{2}-125: 37.5: 25$ NPK (50 per cent RDF), $F_{3}-250: 75: 50$ NPK (100 per cent RDF)].

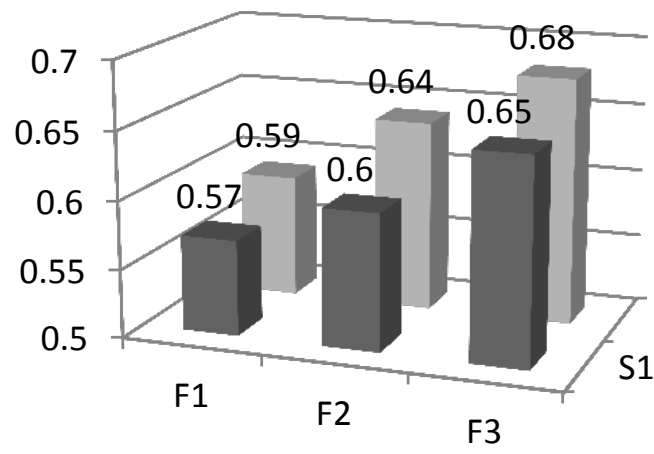

Figure 3: Total K nutrient content (\% per dry weight)) of Salicornia brachiata grown under sea water $\left(S_{1}\right)$ and aquaculture effluent $\left(S_{2}\right)$ irrigation along with various fertilizer levels [ $F_{1}$-no fertilizer (control), $F_{2}-125: 37.5: 25$ NPK (50 per cent RDF), $F_{3}-250: 75: 50$ NPK (100 per cent RDF)].

requirement for optimum growth.

Secondary nutrient content: The range of mean total Ca content of Salicornia in seawater irrigation was 0.24 to $0.33 \%$ (Figure 4). Aquaculture effluent irrigation treatment was significantly higher than seawater irrigation with a range of mean total Ca content of 0.39 to $0.46 \%$. With the increase in RDF the mean total Ca content increased in Salicornia. The mean Ca content ranged from $0.31 \%$ in control to $0.39 \%$ in $100 \% \mathrm{RDF}$. The results showed that Ca content with $100 \% \mathrm{RDF}(\mathrm{F} 3)$ was significantly higher than the $50 \% \mathrm{RDF}$ (F2) and control plot (F1). The increase in Ca content with increase in fertilizer dose may be due to secondary effect from the use of SSP fertilizer also the heavy nutrient load in aquaculture effluent contributed to the increase in Ca content in Salicornia.

The range of mean total $\mathrm{Mg}$ content is 0.80 to $0.85 \%$ under seawater irrigation plots (Figure 5). At the same time the mean total Mg content under aquaculture effluent irrigation ranged from 0.85 to $0.90 \%$. The data indicates aquaculture irrigation significantly accumulated higher amount than seawater irrigation. Fertilizer application increased the $\mathrm{Mg}$ content from 0.83 to $0.88 \%$. Though the $\mathrm{Mg}$ content increased 
Citation: Singh N, Tasung A, Tripathi S, Patel PB, Bafna AM, et al. (2015) Aquaculture Effluent: Effect on Yield, Nutrient Content and Uptake in Salicornia bachiata Roxb. J Aquac Res Development 6: 376. doi:10.4172/2155-9546.1000376

Page 4 of 8

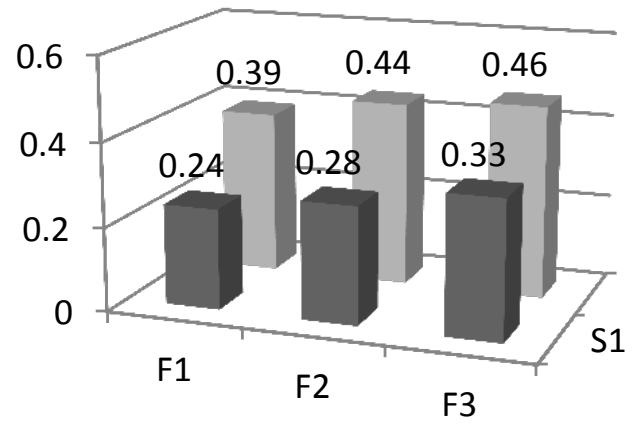

Figure 4: Total Ca nutrient content (\% per dry weight) of Salicornia brachiata grown under sea water $\left(\mathrm{S}_{1}\right)$ and aquaculture effluent $\left(\mathrm{S}_{2}\right)$ irrigation along with various fertilizer levels [ $\mathrm{F}$-no fertilizer (control), $\mathrm{F}-125: 37.5: 25$ NPK (50 per cent RDF), $F_{3}-250: 75: 50$ NPK (100 per cent RDF)].

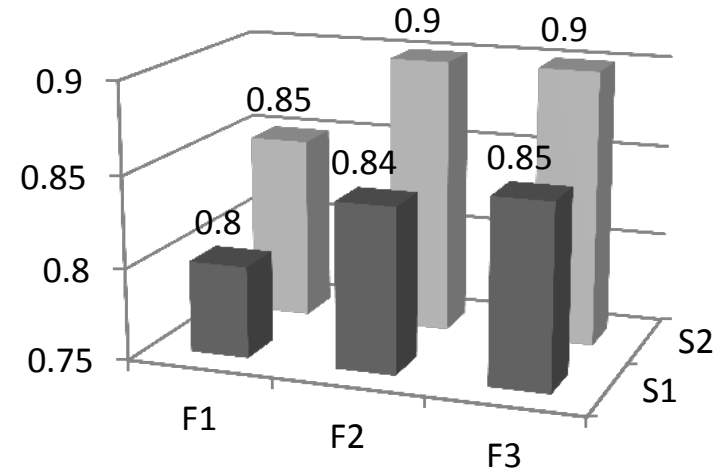

Figure 5: Total Mg nutrient content (\% per dry weight) of Salicornia brachiata grown under sea water $\left(S_{1}\right)$ and aquaculture effluent $\left(S_{2}\right)$ irrigation along with various fertilizer levels [ $F_{1}$-no fertilizer (control), $F_{2}-125: 37.5: 25$ NPK (50 per cent RDF), $F_{3}-250: 75: 50$ NPK (100 per cent RDF)].

with an application of fertilizer there was no significant difference at 5\% level between 50\% RDF (F2) and 100\% RDF (F3). This indicates that Salicornia can meet their Mg requirement with 125:37.5:25 NPK fertilizer dose i.e., 50\% RDF. Simultaneously irrigation with aquaculture effluent also add to the nutrient enhancement of total $\mathrm{Mg}$ content in Salicornia.

In the study we observed the mean range of total $\mathrm{S}$ content in Salicornia was from 0.58 to $0.60 \%$ under seawater irrigation (Figure 6). The study found that there was no significant difference between F2 (50\% RDF) and $\mathrm{F} 3(100 \% \mathrm{RDF})$ treatment at 5\% level of significance. But both F2 and F3 were significantly higher than the control treatment F1. Principally, it indicates that with an application of $50 \%$ RDF plant optimum nutrient requirement was met. The aquaculture effluent irrigation treatment showed superiority in total S content over the seawater irrigation treatment with the same levels of RDF. Surprisingly, there was no significant difference in the aquaculture effluent irrigation even as the RDF was increased at $5 \%$ level of significance. This must be due to presences of sufficient available $S$ in the aquaculture effluent which could meet the plant optimum requirement even in absence of fertilizer. This may have occurred as if, availability is not the limiting factor and then the plant metabolism used only that specific amount required.

The result showed that the total $\mathrm{Na}$ content in Salicornia ranged from 9.00 to $9.11 \%$ under seawater irrigation (Figure 7). When aquaculture effluent was applied as irrigation water the total Na content ranged from 9.04 to $9.12 \%$. Aquaculture effluent irrigation (S2) was found to be significant in total Na content in Salicornia than seawater irrigation (S1). When fertilizer was applied the total $\mathrm{Na}$ content in the F3 plot (100\% RDF) showed to have significantly highest total $\mathrm{Na}$ content. Halophytes are $\mathrm{Na}$ loving plant. Therefore, $\mathrm{Na}$ content in Salicornia increased with fertilizer application and irrigation with aquaculture effluent.

\section{Nutrient uptake}

Primary nutrient uptake: Then mean $\mathrm{N}$ uptake by Salicornia ranged from 5.89 to $30.59 \mathrm{~kg} / \mathrm{ha}$ under seawater irrigation (Table 4). At the same time, in aquaculture effluent irrigation treatment the mean N uptake by Salicornia ranged from 12.52 to $45.75 \mathrm{~kg} / \mathrm{ha}$ and

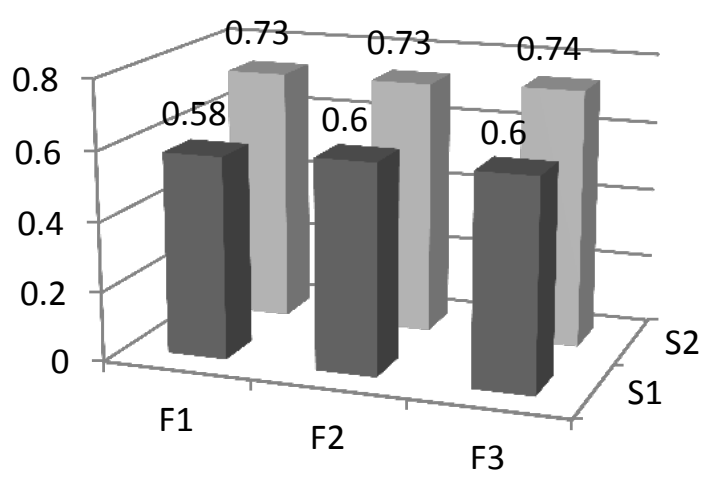

Figure 6: Total S nutrient content (\% per dry weight) of Salicornia brachiata grown under sea water $\left(S_{1}\right)$ and aquaculture effluent $\left(S_{2}\right)$ irrigation along with various fertilizer levels $\left[F_{1}\right.$-no fertilizer (control), $F_{2}-125: 37.5: 25$ NPK (50 per cent RDF), $F_{3}-250: 75: 50$ NPK (100 per cent RDF)].

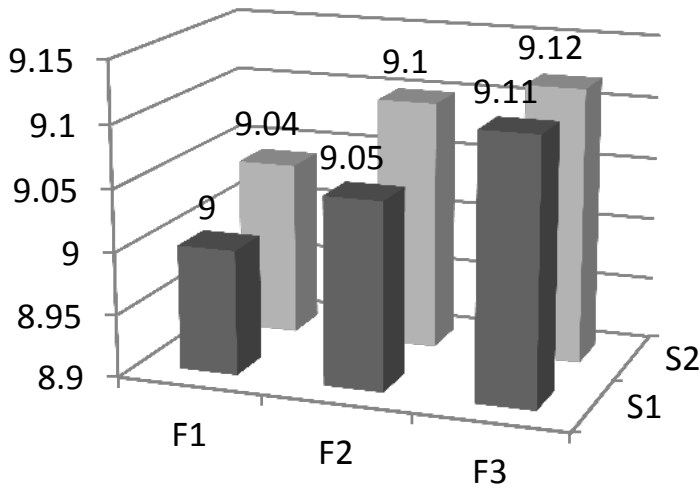

Figure 7: Total Na nutrient content (\% per dry weight) of Salicornia brachiata grown under sea water $\left(S_{1}\right)$ and aquaculture effluent $\left(S_{2}\right)$ irrigation along with various fertilizer levels [ $F_{1}$-no fertilizer (control), $F_{2}-125: 37.5: 25$ NPK (50 per cent RDF), $F_{3}-250: 75: 50$ NPK (100 per cent RDF)]. 
Citation: Singh N, Tasung A, Tripathi S, Patel PB, Bafna AM, et al. (2015) Aquaculture Effluent: Effect on Yield, Nutrient Content and Uptake in Salicornia bachiata Roxb. J Aquac Res Development 6: 376. doi:10.4172/2155-9546.1000376

Page 5 of 8

was significantly higher than in seawater irrigation. The aquaculture effluent containing huge amount of fish feed must have contributed to the significant difference in $\mathrm{N}$ uptake. The mean $\mathrm{N}$ uptake in $100 \%$ RDF (F3) treatment was significantly higher than F2 treatment and control. Fertilizer application contributed to the enhancement of plant optimum growth subsequently increasing the uptake.

Salicornia P uptake recorded in the range 1.58 to $7.76 \mathrm{~kg} / \mathrm{ha}$ under the seawater irrigation treatment (Table 4). Consequently the aquaculture effluent irrigation recorded a significantly higher range of 3.12 to $12.92 \mathrm{~kg} / \mathrm{ha} \mathrm{P}$ uptake by Salicornia than in the seawater irrigation. The high phosphorous nutrient and good soil condition on application of effluent must have contributed to the efficient uptake by Salicornia in the aquaculture effluent plots. In addition, use of fertilizer attributed to the uptake of $\mathrm{P}$ by the roots. A vast difference in $\mathrm{P}$ uptake by Salicornia in the control plot, without fertilizer application $(2.35 \mathrm{~kg} /$ ha) and in the $100 \%$ RDF applied plot $(10.34 \mathrm{~kg} / \mathrm{ha})$. The P uptake by Salicornia in $100 \%$ RDF plot (F3) $(10.34 \mathrm{~kg} / \mathrm{ha})$ was significant and higher than the control plot $(2.35 \mathrm{~kg} / \mathrm{ha})$ and $50 \%$ RDF plot $(7.44$ $\mathrm{kg} / \mathrm{ha}$ ). The use of SSP fertilizer and good physical and chemical soil condition must contribute to the significant uptake by Salicornia in the $100 \%$ RDF applied plot.

Salicornia K uptake recorded a range of 7.41 to $22.69 \mathrm{~kg} / \mathrm{ha}$ under seawater irrigation (Table 4 ). While with aquaculture effluent irrigation the K uptake by Salicornia ranged from 10.74 to $34.04 \mathrm{~kg} / \mathrm{ha}$ that was significantly higher than in seawater irrigation. With an application of $100 \% \mathrm{RDF}(\mathrm{F} 3)$ the plant K uptake was significant $(28.36 \mathrm{~kg} / \mathrm{ha})$ and higher over the control and F2. Murate of potash (MoP) is a water soluble fertilizer. Thus nutrient $\mathrm{K}$ will be present mostly in soil solution which can be easily extracted by the plant root system.
Secondary nutrient uptake: The plant mean Ca uptake ranged from 3.14 to $11.53 \mathrm{~kg} / \mathrm{ha}$ under seawater irrigation (Table 5). When aquaculture effluent was used for irrigation the $\mathrm{Ca}$ uptake by plants increased and ranged from 6.9 to $23.17 \mathrm{~kg} / \mathrm{ha}$. Aquaculture effluent irrigation showed significantly higher $\mathrm{Ca}$ uptake by plants than seawater. The $100 \%$ RDF (F3) was significantly higher in Ca uptake $(17.35 \mathrm{~kg} / \mathrm{ha})$ by the plants than control treatment (F1) $(5.02 \mathrm{~kg} / \mathrm{ha})$ and $50 \% \mathrm{RDF}(\mathrm{F} 2)(14.21 \mathrm{~kg} / \mathrm{ha})$. The application of fertilizer also added to the increase in Ca uptake. The secondary nutrient present in the primary fertilizer must have also come into the soil solution that was readily available to the plant roots.

Salicornia mean Mg uptake ranged from 10.56 to $30.06 \mathrm{~kg} / \mathrm{ha}$ when seawater was employed for irrigation purpose (Table 5 ). In substitute for seawater when aquaculture effluent was used for irrigation the $\mathrm{Mg}$ uptake by plants ranged from 15.56 to $45.71 \mathrm{~kg} / \mathrm{ha}$. Thus $\mathrm{Mg}$ uptake under aquaculture effluent irrigation was significant over seawater irrigation. The considerable amount of $\mathrm{Mg}$ in the aquaculture effluent water must have been present in readily plant available form in soil solution. With the increase in fertilizer dose the $\mathrm{Mg}$ uptake by the plants also increased. The $100 \%$ RDF (F3) plot recorded $37.88 \mathrm{~kg} / \mathrm{ha}$ $\mathrm{Mg}$ uptake which was significant over control (F1) $(13.06 \mathrm{~kg} / \mathrm{ha})$ and $50 \%$ RDF (F2). Use of fertilizer enhances optimum plant growth and development. Thus strong and healthy root can absorb sufficient $\mathrm{Mg}$ for its metabolism.

Salicornia mean S uptake ranged from 7.6 to $21.29 \mathrm{~kg} / \mathrm{ha}$ under seawater irrigation (Table 6). The mean range of S uptake by Salicornia under aquaculture effluent irrigation is 13.06 to $37.29 \mathrm{~kg} / \mathrm{ha}$. In the case of $\mathrm{S}$ uptake the data indicates, irrigation with aquaculture effluent was significantly higher than in seawater irrigation. Salicornia being an oil seed crop require higher quantity of $S$ nutrient. Therefore, $S$ uptake

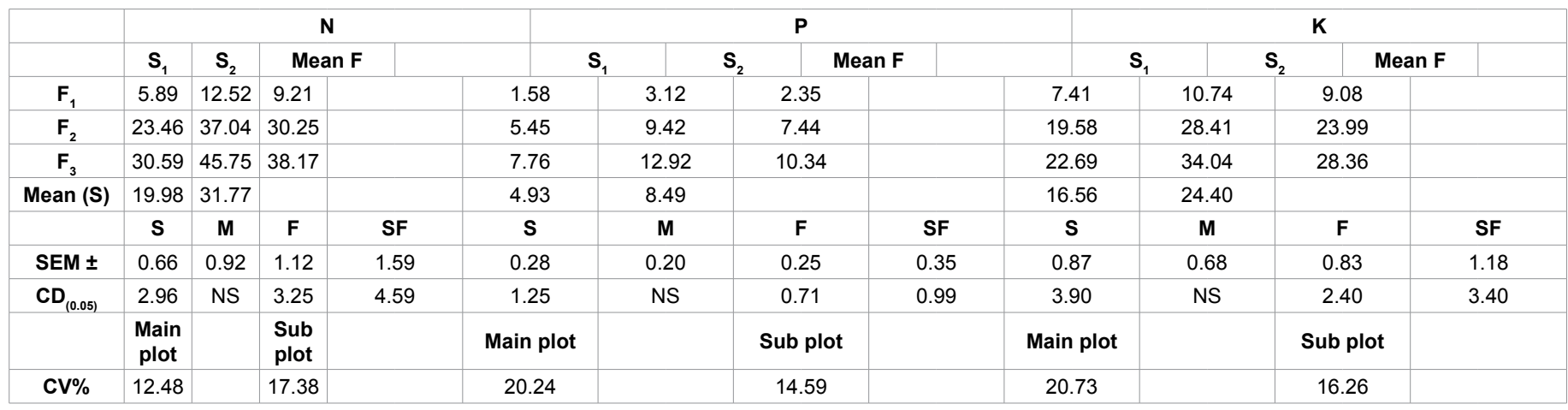

Table 4: Effect of sea water $\left(\mathrm{S}_{1}\right)$ and aquaculture effluent $\left(\mathrm{S}_{2}\right)$ irrigation along with various fertilizer levels [ $\mathrm{F}_{1}$-no fertilizer (control), $\mathrm{F}_{2}-125: 37.5: 25 \mathrm{NPK}(50$ percent $\mathrm{RDF}$ ), $\mathrm{F}_{3}-250: 75: 50 \mathrm{NPK}$ (100 percent RDF)] on uptake of N, P and K nutrients (kg/ha) by Salicornia brachiate.

\begin{tabular}{|c|c|c|c|c|c|c|c|c|}
\hline & \multicolumn{4}{|c|}{$\mathrm{Ca}$} & \multicolumn{4}{|c|}{ Mg } \\
\hline & $\mathrm{S}_{1}$ & $S_{2}$ & Mean F & & $\mathrm{S}_{1}$ & $S_{2}$ & Mean F & \\
\hline$F_{1}$ & 3.14 & 6.90 & 5.02 & & 10.56 & 15.56 & 13.06 & \\
\hline$F_{2}$ & 9.02 & 19.39 & 14.21 & & 27.32 & 40.21 & 33.77 & \\
\hline$F_{3}$ & 11.53 & 23.17 & 17.35 & & 30.06 & 45.71 & 37.88 & \\
\hline \multirow[t]{2}{*}{ Mean (S) } & 7.90 & 16.49 & & & 22.65 & 33.83 & & \\
\hline & S & M & $\mathbf{F}$ & SF & $S$ & $M$ & $\mathbf{F}$ & SF \\
\hline SEM \pm & 0.31 & 0.38 & 0.46 & 0.65 & 0.71 & 1.02 & 1.25 & 1.77 \\
\hline \multirow[t]{2}{*}{$C D_{(0.05)}$} & 1.37 & NS & 1.34 & 1.89 & 3.20 & NS & 3.61 & 5.10 \\
\hline & Main plot & & Sub plot & & Main plot & & Sub plot & \\
\hline CV\% & 12.27 & & 15.16 & & 12.33 & & 17.69 & \\
\hline
\end{tabular}

Table 5: Effect of sea water $\left(\mathrm{S}_{1}\right)$ and aquaculture effluent $\left(\mathrm{S}_{2}\right)$ irrigation along with various fertilizer levels [ $\mathrm{F}_{1}$-no fertilizer (control), $\mathrm{F}_{2}-125: 37.5: 25 \mathrm{NPK}(50$ percent $\mathrm{RDF}$ ), $\mathrm{F}_{3}-250: 75: 50 \mathrm{NPK}$ (100 percent RDF)] on uptake of Ca and Mg nutrients (kg/ha) by Salicornia brachiate. 
Citation: Singh N, Tasung A, Tripathi S, Patel PB, Bafna AM, et al. (2015) Aquaculture Effluent: Effect on Yield, Nutrient Content and Uptake in Salicornia bachiata Roxb. J Aquac Res Development 6: 376. doi:10.4172/2155-9546.1000376

Page 6 of 8

\begin{tabular}{|c|c|c|c|c|c|c|c|c|}
\hline & \multicolumn{4}{|c|}{$\mathbf{S}$} & \multicolumn{4}{|c|}{$\mathrm{Na}$} \\
\hline & $S_{1}$ & $S_{2}$ & Mean F & & $S_{1}$ & $S_{2}$ & Mean F & \\
\hline$F_{1}$ & 7.60 & 13.06 & 10.33 & & 118 & 165 & 141 & \\
\hline$F_{2}$ & 19.40 & 32.81 & 26.11 & & 296 & 409 & 352 & \\
\hline$F_{3}$ & 21.29 & 37.29 & 29.29 & & 323 & 462 & 392 & \\
\hline \multirow[t]{2}{*}{ Mean (S) } & 16.10 & 27.72 & & & 246 & 345 & & \\
\hline & $\mathbf{S}$ & M & $\mathbf{F}$ & SF & $S$ & M & $\mathbf{F}$ & SF \\
\hline SEM \pm & 0.72 & 0.75 & 0.92 & 1.30 & 9.27 & 9.98 & 12.22 & 17.28 \\
\hline \multirow[t]{2}{*}{$C D_{(0.05)}$} & 3.241 & NS & 2.653 & 3.751 & 41.69 & NS & 35.29 & 49.91 \\
\hline & Main plot & & Sub plot & & Main plot & & Sub plot & \\
\hline CV\% & 16.10 & & 16.77 & & 15.37 & & 16.56 & \\
\hline
\end{tabular}

Table 6: Effect of sea water $\left(\mathrm{S}_{1}\right)$ and aquaculture effluent $\left(\mathrm{S}_{2}\right)$ irrigation along with various fertilizer levels $\left[\mathrm{F}_{1}\right.$-no fertilizer (control), $\mathrm{F}_{2}-125: 37.5: 25 \mathrm{NPK}(50$ per cent $\mathrm{RDF}$ ), $\mathrm{F}_{3}-250: 75: 50 \mathrm{NPK}(100$ per cent RDF)] on uptake of $\mathrm{S}$ and Na nutrients $(\mathrm{kg} / \mathrm{ha})$ by Salicornia brachiate.

was higher in aquaculture effluent irrigation despite the fact that $\mathrm{SO}_{4}^{-2}$ nutrient in the aquaculture effluent was slightly lower than the sea water (Table 2). The S content being higher in aquaculture effluent treated plant must have been due to the presences of higher soil available $S$ content in the aquaculture effluent plots (Table 1). The Salicornia S uptake of $29.29 \mathrm{~kg} / \mathrm{ha}$ in $100 \%$ RDF plot (F3) (Table 6) was found to be significant and higher than the control treatment (F1) and 50 percent RDF treatment (F2). This indicates that significance of S uptake in F3 plot might be due to the secondary nutrient present in the primary fertilizer which was absorbed by the vigorous root system.

The uptake of Na by Salicornia ranged from 118 to $323 \mathrm{~kg} / \mathrm{ha}$ under seawater irrigation (Table 6). The mean range of $\mathrm{Na}$ uptake under aquaculture effluent irrigation is 165 to $462 \mathrm{~kg} / \mathrm{ha}$. The data indicates that aquaculture effluent treated plants were significantly higher than seawater irrigation. Apparently, the high $\mathrm{Na}$ content in aquaculture effluent is due to the reuse of the saline shrimp culture water to irrigate the plants. Na nutrient is essential for optimum functioning of Salicornia which was met from the saline aquaculture effluent. Use of fertilizer caused an increase in Na uptake. In the 100\% RDF (F3) treatment the $\mathrm{Na}$ uptake was $392 \mathrm{~kg} / \mathrm{ha}$. Therefore, $\mathrm{F} 3$ treatment was significant and higher than the control F1 and 50\% RDF F2 treatment.

\section{Discussion}

\section{Effect of aquaculture effluent and fertilizer application on fresh and dry biomass yield}

The fresh and dry biomass yield was significantly higher in fertilizer treated plots than in control treatment plots. The fresh and dry biomass yield showed higher trend with increasing fertilizer application in F2 and F3 fertilizer treatment in both seawater and aquaculture effluent irrigation treatment.

The fresh and dry biomass production was higher in F1, F2 and F3 fertilizer treatment plots irrigated with aquaculture effluent as compared to F1, F2 and F3 fertilizer treatment plots irrigated with sea water.

It was reported $S$. bigelovii needs extremely high quantities of $\mathrm{N}$ fertilizer $[24,25]$. Thus in the present study, $100 \% \mathrm{RDF}$ along with aquaculture effluent recorded highest fresh and dry biomass yield. This is because the nutrient present in aquaculture effluent also contributed to the crop's excessively higher requirement of nutrient. The results agreed with those of Sollenbergs [26] and Butler [27], who concluded that nutrients in waste water increased crop growth and yield.

\section{Effect of aquaculture effluent and fertilizer application on nu- trient content and uptake}

Effect of aquaculture effluent and fertilizer application on primary nutrient content and uptake: Salicornia brachiata Roxb. total $\mathrm{N}$ content in the above ground part was significantly higher when irrigated with aquaculture effluent than with the application of seawater. In the current study it was reported that with an increase in NPK levels the total N content in Salicornia brachiata also increased. The amide nitrogen fertilizer i.e. Urea was used in the research. This report agreed with Tikhomirova [28] and Ushakova [29] who found that Salicornia europaea plants could grow on mediums containing nitrogen both in nitrate and amide forms and had practically similar productivity.

In the study, the interaction effect of source of irrigation (S) and levels of fertilizer (F) was significant in total $\mathrm{N}$ content of Salicornia brachiata Roxb. The interaction of aquaculture effluent irrigation $\left(\mathrm{S}_{2}\right)$ and $100 \% \operatorname{RDF}\left(\mathrm{F}_{3}\right)$ was significant and higher in total $\mathrm{N}$ content of Salicornia than aquaculture effluent irrigation interaction with no fertilizer $\left(\mathrm{F}_{1}\right)$ and $50 \% \operatorname{RDF}\left(\mathrm{F}_{2}\right)$ and also significantly higher than seawater irrigation interaction with levels of fertilizer. Brown [15] found that salinity (35ppt) had a significant inhibitory effect on total nitrogen content in the Salicornia shoot. The N content decreased from $0.58 \%$ at $10 \mathrm{ppt}$ to $0.20 \%$ at $35 \mathrm{ppt}$ salinity of water supplied. Thus, in the current study the $\mathrm{EC}_{(1: 2.5)}$ in aquaculture effluent was $43.97(\mathrm{dS} / \mathrm{m})$ which was considerable low to have an adversity on an obligate halophyte, Salicornia . In comparison, Al-Jaloud [30] found that with 25 to $50 \%$ $\mathrm{N}$ application under aquaculture effluent irrigation were comparable with those obtained with 75 and $100 \% \mathrm{~N}$ application under well water irrigation.

In the end of the study, the total P content of Salicornia brachiata Roxb. was found to be higher in aquaculture irrigation plot than seawater irrigation. Also total $\mathrm{P}$ content increased with increase in fertilizer levels from no fertilizer to $100 \%$ RDF. Brown [15] found that the aquaculture effluent (intensive talipia aquaculture) used for irrigation in the experiment was substantially higher in $\mathrm{N}$ and $\mathrm{P}$ concentration than typical mariculture effluent. In consensus to the above finding residual $\mathrm{P}$ concentration in the aquaculture effluent used as irrigation water increased the P content of Salicornia in the current study. Hegedus [31] found the nutrient uptake rates of the aerial biomass of macrophytes (Aster tripolium spp. tripolium, Bolboschoenus maritimus, Glyceria maxima, Scirpus lacustris spp. tabernaemontani, Triglochin palustris, Phragmites australis, Typha angustifolia, Carex vulpina, ) were in the range of $0.218-1.38 \mathrm{~g} / \mathrm{m}^{2} /$ day, 0.019 $0.176 \mathrm{~g} / \mathrm{m}^{2} /$ day and $0.154-0.602 \mathrm{~g} / \mathrm{m}^{2} /$ day for $\mathrm{N}, \mathrm{P}$ and $\mathrm{K}$ respectively, when treated with effluent water. 
Again, in the study it was observed that total K content in Salicornia brachiata Roxb. was higher in the aquaculture effluent irrigation than seawater irrigation. Ventura [32] reported that K content in Salicornia was significant with increase in seawater concentration $(50 \%, 75 \%$ and $100 \%)$ and attained highest $\mathrm{K}$ content with $100 \%$ seawater concentration $(0.3 \%)$. It was observed in the current study that with an increase in application of fertilizer level recomndation the total $\mathrm{K}$ content in Salicornia shoots also increased.

Effect of aquaculture effluent and fertilizer application on secondary nutrient content and uptake: The total $\mathrm{Ca}$ content in Salicornia brachiata Roxb. was higher when aquaculture effluent irrigation was completed than with seawater irrigation and Ca content increased with increase in RDF. Prevalence of similar trend in total $\mathrm{Mg}$ content was observed with aquaculture effluent application and also total $\mathrm{Ca}$ content increased with increase in RDF. However the total $\mathrm{Mg}$ content was higher than the total $\mathrm{Ca}$ content in all the treatments (Figures 4 and 5). Thus $\mathrm{Mg}$ content indicated to be higher than $\mathrm{Ca}$ content. This primarily may be due to the antagonistic effect of $\mathrm{Ca}$ and $\mathrm{Mg}$.

Apparently, the total S content in aquaculture effluent irrigation plots was higher than seawater irrigation water plots. The application of increasing levels of RDF saw a simultaneous increase in total S content of Salicornia brachiata Roxb. The primary P fertilizer used was SSP which contain 12 to $16 \%$ S which provided the nutrient S requirement thereby increasing the nutrient content in the plant. Although the aquaculture effluent measured a lower amount of $\mathrm{SO}_{4}^{-2}$ than seawater, the soil available $\mathrm{S}$ content was higher in the aquaculture effluent plot than seawater treated plot. The presence of available form of $S$ nutrient in soil might have facilitated the absorption by the roots which thereby caused a higher nutrient content in aquaculture effluent irrigated plot than in seawater irrigated plot. Khan [33] reported that $\mathrm{SO}_{4}^{2-}$ content $(98.7 \pm 15.0$ $\mathrm{mM}$ ) attained highest amount at $200 \mathrm{mM} \mathrm{NaCl}$ salinity. The soil $\mathrm{EC}_{(1: 2.5)}$ of the experimented plot was well maintained in the adequate range need for survival of obligate halophyte Salicornia brachiata Roxb in aquaculture effluent treated plots as compared to plots under seawater irrigation.

Apparently, total $\mathrm{Na}$ content and uptake was 7-8 times higher than Ca content and uptake. Amiri and Rasouli [34]observed ion content in Salicornia herbacea root and shoot and showed that $\mathrm{K}$ and $\mathrm{Na}$ were higher in shoot and $\mathrm{Na}_{2} \mathrm{SO}_{4}$ salt, while Ca content was more in root and $\mathrm{NaCl}$ salt. They also reported that as salinity increases $\mathrm{K}, \mathrm{Mg}$ content and decreased Ca content. $\mathrm{Lu}$ [35] reported that $\mathrm{Na}$ and its concentration predominated in the plant mineral composition and amounted to about $1 \%$ of fresh weight, which was the reason why $S$. bigelovii would not be directly used as a staple food source. Martinez-Gracia [36] abstracted from the findings that the primary cation $\mathrm{Na}$ involved in osmotic adjustment of $\mathrm{S}$. begilovii, apparently stimulates growth by mechanisms apart from its role as an osmoticum. Martinez-Gracia [36] found that Salicornia bigelovii plants varied little in their uptake of $\mathrm{Na}$ for osmotic adjustment while $\mathrm{Na}$ in shoots differed significantly among treatments increasing with increased salinity with $18 \% \mathrm{Na}$ of dry weight at $0.35 \mathrm{M} \mathrm{NaCl}$. Waisel [37] classified S. europaea as an obligate halophyte because growth was stimulated by $\mathrm{NaCl}$ increments.

Therefore, from the result it indicates that the presences of organic and inorganic forms of nutrient in the aquaculture effluent had a conclusive significant effect on the plant $\mathrm{N}$ content. The data shows evidence that aquaculture effluent contain plant available $\mathrm{P}$ nutrient required for active metabolism.

\section{Conclusion}

The potential of Salicornia to withstand the nutrient load from aquaculture effluent and respond to high dose of fertilizer is evident from the fresh biomass yield in spite of using high EC aquaculture effluent and seawater as irrigation. The nutrient content and uptake increased as the biomass increased to conduct their metabolic activity. To our findings Salicornia accumulated appreciable quantity of secondary nutrients that can be used to medicate various oxidative reactions. Though the soil fertility was intact after harvest due consideration must be given to avoid any future soil problems. Brown [15] suggested extensive field testing and site considerations would be needed before saline aquaculture effluent could be used to grow crops at a given location, due to the potential hazards presented by the salt as well as the nutrient load.

\section{Acknowlegement}

We would like to thank Dean of N.M. College, Navsari Agricultural University, Navsari and Central Instrumentation Laboratory, Navsari Agricultural University, Navsari, for providing necessary requirements in conducting the research and we also express our gratitude to Acquaculture Research and Development Foundation for their support during the research.

\section{Conflict of interest}

The authors declare that they have no financial or personal relationships which may have inappropriately influenced them in writing this paper and there are no conflicts of interest.

\section{References}

1. Gowen RJ, Bradbury NB (1987) The ecological impact of salmonid farming in the coastal waters: a review. Oceanography and Marine Biology: an Annual Review 25: 563-575

2. Bell PRF, Greenfield PF, Hawker D, Connell D (1989) The impact of waste discharges on coral reef regions. Water Science and Technology 21: 121-130.

3. Iwama GK (1991) Interactions between aquaculture and the environment Critical Reviews in Environmental Control 21: 177-216.

4. Handy RD, Poxton MG (1993) Nitrogen pollution in mariculture: toxicity and excretion of nitrogenous compounds by marine fish. Reviews in Fish Biology and Fisheries 3: 205-241.

5. Hopkins JS, Sandifer PA, Devoe MR, Holland AF, Browdy CL, et al. (1995) Environmental impact of shrimp farming with special reference to the situation in the Continental United States. Estuaries 18: 25-42.

6. Wu RSS (1995) The environmental impact of marine fish culture: towards a sustainable future. Marine Pollution Bulletin 31: 159-166.

7. Costa-Pierce BA (1996) Environmental impacts of nutrients from aquaculture: towards the evolution of sustainable aquaculture systems. In: Baird DJ Beveridge MCM, Kelly LA, Muir JF (eds.) Aquaculture and Water Resource Management. Blackwell Science, Oxford pp: 81-113.

8. Dierberg FE, Kaittisimkul W (1996) Issues, impacts and implications of shrimp aquaculture in Thailand. Environmental Management 20: 649-666.

9. Rakocy JE, Hargreaves JA (1993) Integration of vegetable hydroponics with fish culture: a review. In: Wang JK (eds.) Techniques for Modern Aquaculture. ASAE, St Joseph MI pp: 159-165.

10. Glenn EP, O'Leary JW, Watson MC, Thomas TL, Kuehl RO (1991) Salicornia bigelói ii Torr.: an oilseed halophyte for seawater irrigation. Science 251: 10651067.

11. Glenn EP, Swingle RS, Riley JJ, Squires VR, Mota CU, et al. (1994) North American halophytes: potential use in animal husbandry. Kluwer Academy Publishers 32: 165-174.

12. Glenn EP, Miyamoto S, Moore D, Brown JJ, Thompson TL, et al. (1997) Water requirements for cultivating Salicornia bigelolii Torr. with seawater on sand in a coastal desert environment. J Arid Environ 36: 711-730.

13. Miyamoto S, Glenn EP, Olsen MW (1996) Growth, water use and salt uptake of 
Citation: Singh N, Tasung A, Tripathi S, Patel PB, Bafna AM, et al. (2015) Aquaculture Effluent: Effect on Yield, Nutrient Content and Uptake in Salicornia bachiata Roxb. J Aquac Res Development 6: 376. doi:10.4172/2155-9546.1000376

Page 8 of 8

four halophytes irrigated with highly saline water. Journal of Arid Environments 32: 141-159.

14. Swingle RS, Glenn EP, Squires VR (1996) Growth performance of lambs fed mixed diets containing halophyte ingredients. Anim Feed Sci Tech 63: 137-148.

15. Brown JJ, Glenn EP, Fitzsummons KM, Smith SE (1999) Halophyte for the treatment of saline aquaculture effluent. Aquaculture 175: 255-268.

16. Pandya JB, Gohil RH, Patolia JS, Shah MT, Parmar DR (2006) A study on Salicornia (S. brachiata Roxb.) in salinity ingressed soils of India. International Journal of Agricultural Research 1: 91-99.

17. Jackson ML (1967) Soil Chemical Analysis. Prentice-Hall of India Pvt. Ltd., New Delhi.

18. Subbiah BV, Asija GL (1956) A rapid procedure for determination of available nitrogen in soils. Current Science 25: 259-260.

19. Olsen SR, Cole CV, Watanabe FS, Dean LA (1954) Estimation of available phosphorus in soils by extraction with sodium bicarbonate. USDA Circular 939 U.S. Government Printing Office, Washington DC.

20. Black CA (1965) Methods of Soil Analysis, Part I. Am. Soc. Agron., Wisconsin, USA.

21. American Public Health Association, American Water Works Association, Water Environment Federation, 1995. Standard Methods for the Examination of Water and Wastewater. American Public Health Association, Washington, DC.

22. Tandon HLS (2005) Methods of analysis of soil, plants, waters, fertilizers and organic matter, second ed. Fertilizer Development and Consultation Organization, New Delhi pp: 76-111.

23. Panse VG, Sukhatme PV (1985) Statistical Methods for Agricultural Workers (4thedn.) ICAR, New Delhi 347.

24. Mota U (1996) Levels of fertilizer in Salicornia bigelovii. In: Proceedings of First International Technical Seminar for Salicornia. Planetary Design Corporation. Puerto Peñasco, Sonora, Mexico p: 96.

25. Rueda-Puente EO, Castellanos T, Troyo-Diéguez E, Diaz de Leon Alvarez $\mathrm{JL}$ (2004) Effect of Klebsiella pneumonia and Azospirillum halopraeferens on the growth and development of two Salicornia bigelovii genotypes. Australian Journal of Experimental Agriculture 44: 65-74.
26. Sollenbergs $\mathrm{G}$ (1981) Farming with higher-priced fertilizer: It's back to basics. The Furrow 6: 12-15.

27. Butler JL, Johnson JC, Newton GL, Hubbard RK (1986) Forage production using dairy flush/waste water. Am Soc Agric Eng 86: 1034-1041.

28. Tikhomirov AA, Ushakova SA, Kovaleva NP, Kudenko Yu A, Zolotukhin IG et al. (2005) Some ways of waste utilization for a bioregenerative life support system. In: Proceedings of the International Symposium on Closed Habitation Experiments and Material Circulation Technology Japan, pp. 10-213.

29. Ushakova SA, Kovaleva NP, Tikhomirova NA, Gribovskaya IV, Kolmakova AA (2006) Effect of photosynthetically active radiation, salinization, and type of nitrogen nutrition on growth of Salicornia europaea plants. Russian Journal of Plant Physiology 53: 785-792.

30. Al-Jaloud AA, Hussain G (1993) Use of aquaculture effluent as a supplemental source of nitrogen fertilizer to wheat Crop. Arid Soil Research and Rehabilitation 7: 233-241.

31. Hegedus R, Kerepeczki E, Gal D, Pekar F, Oncsik MB, et al. (2010) Potential Role of Halophytic Macrophytes in Saline Effluent Treatment. World Academy of Science, Engineering and Technology 4: 198-202.

32. Ventura Y, Wuddineh WA, Shpigel M, Samocha TM, Klim BC, et al. (2011) Effects of day length on flowering and yield production of Salicornia and Sarcocornia species. Scientia Horticulturae 130: 510-516.

33. Khan MA, Gill B, Weber DJ (2001) Effect of salinity on the growth and ion content of Salicornia rubra. Commun Soil Sci and Plant Anal 32: 2965-2977.

34. Amiri B, Rasouli B (2011) How does the root of Salicornia herbacea response to salinity in comparison to the shoot? International Conference on Biotechnology and Environment Management 18: 88-92.

35. Lu D, Zhang M, Wang S, Cai J, Zhou X, et al. (2010) State Nutritiona characterization and changes in quality of Salicornia bigelovii Torr. during storage. LWT - Food Science and Technology 43: 519-524.

36. Martinez-Garcia R (2010) Physiological studies of the halophyte Salicornia bigelovii: A potential food and biofuel crop for integrated aquaculture agriculture systems. PhD Thesis, University of Arizona, USA.

37. Waisel Y (1972) Biology of Halophytes. Academic Press, New York, NY p: 395 